\title{
Florida Crop/Pest Management Profile: Lettuce ${ }^{1}$
}

Mark A. Mossler and Esther Dunn²

\section{Contents}

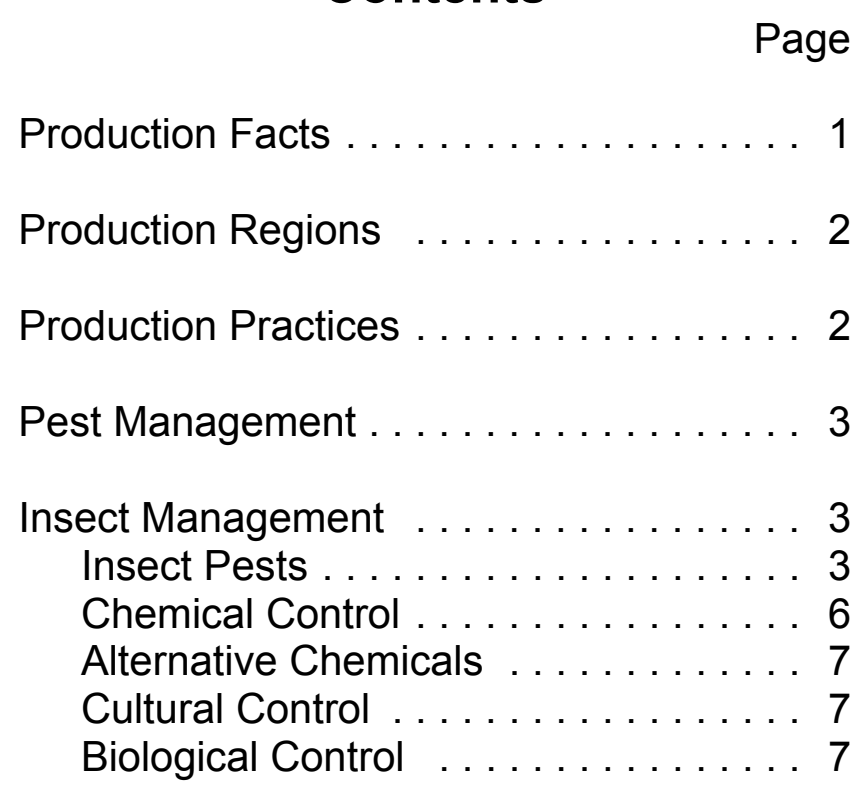

Disease Management . . . . . . . . . 8

Disease Pathogens . . . . . . . . . . 8

Chemical Control . . . . . . . . . . . . . . 9

Alternative Chemicals . . . . . . . . . 10

Cultural Control . . . . . . . . . . . . 10

Biological Control .......... 10
Nematode Management . . . . . . . . . . . . . 11

Nematode Pests . . . . . . . . . . . . 11

Weed Management . . . . . . . . . . . 11

Weed Pests . . . . . . . . . . . . . . . . . . 11

Chemical Control . . . . . . . . . . . . 12

Chemical Alternatives . . . . . . . . . 12

Cultural Control . . . . . . . . . . . . . . 13

Key Contacts . . . . . . . . . . . . . . . . 13

References ... . . . . . . . . . . . . 13

\section{Production Facts}

- In 2002, Florida produced less than one percent of U.S. lettuce (head, leaf, or romaine lettuce), which had total combined national acreage of over 306,000 acres (1). Value and production estimates for lettuce have been

1. This document is CIR1460, one of a series of the Pesticide Information Office, Food Science and Human Nutrition Department, Florida Cooperative Extension Service, Institute of Food and Agricultural Sciences, University of Florida. For additional Information, contact the Pesticide Information Office, University of Florida, P. O. Box 110710, Gainesville, Fl 32611-0710, (352) 392-4721. Published February 2005. Please visit the EDIS Web site at http://edis.ifas.ufl.edu

2. Mark A. Mossler, Pest Management Information Specialist, Pesticide Information Office, Food Science and Human Nutrition Department. Esther Dunn, Integrated Pest Management., Entomology and Nematology Department Cooperative Extension Service, Institute of Food and Agricultural Sciences, University of Florida, Gainesville, 32611-0710.

The use of trade names in this publication is solely for the purpose of providing specific information. UF/IFAS does not guarantee or warranty the products named, and references to them in this publication does not signify our approval to the exclusion of other products of suitable composition. Use pesticides safely. Read and follow directions on the manufacturer's label. All chemicals should be used in accordance with directions on the manufacturer's label.

The Institute of Food and Agricultural Sciences (IFAS) is an Equal Employment Opportunity - Affirmative Action Employer authorized to provide research, educational information and other services only to individuals and institutions that function without regard to race, creed, color, religion, age, disability, sex, sexual orientation, marital status, national origin, political opinions or affiliations. For information on obtaining other extension publications, contact your county Cooperative Extension Service office. Florida Cooperative Extension Service / Institute of Food and Agricultural Sciences / University of Florida / Larry R. Arrington, Interim Dean 
discontinued by state agencies since the mid 1990s.

- In Florida lettuce production has declined from a high of 14,000 acres in 1990-91 to a low of 1,250 acres in 1998 (the last year of published values), paralleling the loss or transition of farmable muck soils in the state (2-4). There is believed to be approximately 5,000 acres of lettuce in Florida as of 2004.

- The average cost of lettuce production is $\$ 3,400$ per acre, with yields averaging nearly 30,000 pounds per acre (2).

- There are currently few lettuce growers in Florida, but farm size is generally categorized as large (5).

\section{Production Regions}

Lettuce can be grown throughout the state, but commercial production is concentrated in the muck soil area immediately surrounding Lake Okeechobee (South Bay). There is also some production on mineral soils in the northern part of the state. Production generally occurs from August through February in northern and central Florida, and between late September and May in southern Florida $(6,7)$.

\section{Production Practices}

Traditional head or leaf lettuce is a shortseason crop with maturities from seed ranging from 70 to 95 days; but these times can be shortened by using transplants. Even shorter, spring salad mix lettuce plants grow for only 30 days. Lettuce requires frost-free growing conditions, but is a cool season crop. Although lettuce is produced on a number of soil types, the crop does best on muck soils. It often follows sugarcane or sweet corn in rotation. The optimum $\mathrm{pH}$ for lettuce is 6.0, although the $\mathrm{pH}$ of muck soils may be greatly different than this value. With between row distance of 18 inches and between plant distance of eight inches to one foot, plant densities can range from 29,000 to over 43,000 plants per acre. Seeds are generally sown at a depth of one-quarter inch, which may require from one to four pounds of seed per acre. Seeding for salad mix can be done at levels up to 2.5 million plants per acre $(5,6)$.

Varieties of head lettuce grown in Florida include Gator, Raleigh, and Gulfstream. Varieties of romaine include Terrapin and Snappy, while Two Star green leaf lettuce is often grown. New Redfire and Vulcan are two red leaf lettuce varieties, while Butter Crisp, Ermosa, and Margarita are Boston lettuce varieties. Floribibb is a bibb lettuce cultivar in current use (6).

Historically, head lettuce was the main lettuce farmed in southern Florida. But, this has shifted to leaf lettuce, lettuce for spring salad mixes, and "baby salad" production. Even salad mix operations have declined based on labor availability and cost as compared to California operations. More growers in the production area are also switching to sugarcane production (8).

Fertilizing options for lettuce depend on whether the plants are being produced on muck soils (generally bare ground) or whether they are being produced on mineral sands (generally in conjunction with plastic mulch). Irrigation is by subsurface, sprinkler, or drip-irrigation. Generally, nitrogen is split throughout the season to account for the rapid loss experienced under Florida conditions $(2,6)$.

The north Florida growers utilize plastic mulch to warm the soil, allowing them to grow longer into the winter. In addition to the ability to harvest later, the use of polyethylene mulch aids in weed control and improves the efficiency of water and fertilizer use. When plastic mulch is used, a bed press shapes a smooth bed to maximize contact between the mulch and the bed surface, and fertilizer is added to the bed before 
the mulch is laid down. South Florida growers use plastic mulch mainly for weed control purposes (8).

If this system is employed worker activities for the season commence with laying mulch. The ground is then either directly seeded or transplants are set. During the warmer months, muck soil-produced lettuce is directly seeded, and then thinned (and weeded) three weeks later. In cooler months (and on plastic mulch) transplants are set by hand. Workers setting transplants (approximately five days for a fortyacre farm) often wear latex gloves. For those operations (roughly ten percent) that do not use herbicides, hand weeding is done once more before harvest. A single worker is capable of thinning/hand weeding an acre a day. The only remaining labor includes harvest. Almost all lettuce is picked just once. Sometimes romaine is picked twice if the price is favorable. The spring salad mix lettuce is harvested with a suction-type mechanical harvester (8).

\section{Pest Management}

Since lettuce is a vegetative crop, the most important pest groups in Florida production include the early season diseases, weeds, and leaf-feeding insects. Certain viruses are viewed as emerging pests. Mites and nematodes are generally not problematic in Florida lettuce production.

\section{Insect Management}

\section{Insect Pests}

The principal insect pest group on lettuce grown in Florida is lepidoptera larvae (caterpillars). These include cutworms (granulate, black, variegated), armyworms (beet, fall, and southern), corn earworm, and cabbage looper. Although generally not plant damaging (except as a virus vector), the physical presence of aphids results in downgrading of the crop. Occasional or minor arthropod pests include thrips, seedcorn maggot, seedcorn beetles, cucumber beetles, leafminers, and wireworms. Fire ants sometimes disrupt harvest, or become predators of the lettuce plants for lack of any other vegetation $(7,9)$.

Cutworms [granulate cutworm, (Feltia subterranea), black cutworm (Agrotis ipsilon), variegated cutworm (Peridroma saucia)]. Cutworms are stout caterpillars with a dull, greasy appearance. Cutworms cleave seedlings off at or just below the soil line. They may also bore into heads, and some species may damage leaves. Black cutworms do most of their feeding at ground level; the larvae feeding on young plants and cutting off leaves, or in later instars, entire plants. Populations of cutworms tend to be higher in weedy or wet fields. Granulate cutworm larvae can cut off entire seedling plants, as well as climb and feed on leaves of older plants. This cutworm is not associated with weedy fields as is the black cutworm. First instar larvae stay on the plants, while older larvae climb and feed on plants only during the night.

Variegated cutworms cut off seedlings at ground level or defoliate older plants. They can also be a much more damaging pest in the spring salad mix production (9).

In some areas, natural enemies of cutworms exert control pressure that may approach 80 percent. However, seedlings emerging in fields without this protection can experience substantial stand loss (9).

\section{Beet Armyworm (Spodoptera exigua).}

These larvae feed in the crown of the plant and can severely stunt or kill seedlings. The potential for damage is reduced between thinning and head formation. Beet armyworms may cause serious damage by boring in from the bottom of the head after lettuce head formation.

Larvae emerge from egg masses in three to four days. They feed in groups during the first instar and then disperse on the wind using silken 
threads. Larvae usually feed on the older leaves and move down into the crowns and into heads near the base of the plants. Larvae enter the soil to pupate after two to three weeks of feeding. Adults emerge in 7 to 10 days. Consequently, generations can be spawned monthly. The threshold for treatment is one second or third instar larva per 10 plants from germination to heading, and $>1$ per 25 plants after head formation $(7,9)$.

\section{Southern Armyworm (Spodoptera} eridania). As with beet armyworm, larvae emerge from egg masses in three to four days. They feed in groups during the first instar and then disperse on the wind. Larvae feed on the older leaves and move down into the crowns and into heads near the base of the plants. Larvae enter the soil to pupate after 2 to 3 weeks of feeding. Adults emerge in 7 to 8 days, creating one life cycle in less than a month in some cases. The threshold for treatment is the same as beet armyworm. It has also been noted that the insecticide spinosad is no longer controlling this caterpillar $(7,9)$.

Fall Armyworm (Spodoptera frugiperda). Adults can be seen along the north Florida coast during all months but are most abundant from April to December. The fall armyworm does not enter diapause and cannot survive extended periods of low temperatures, instead maintaining populations in warmer areas from which adults move northward in the spring. Eggs are laid in masses of 100 to 150, and each moth may lay over a thousand eggs in total. Control at the egg stage is extremely difficult, because of the protective covering over the mass and its position on the underside of leaves. Larvae typically damage lettuce plants by leaf and head feeding. Although the life cycle of the fall armyworm can be completed in about 30 days during the summer, it can take 60 days in the spring and fall and up to 90 days during the winter $(10,11)$.

Corn Earworm (Helicoverpa zea). These caterpillars, also called tomato fruitworms and cotton bollworms, attack a wide variety of vegetable and field crops. Young larvae feed on outer leaves before moving into the more protected inner leaves. They can destroy seedlings by feeding on the crown and they can affect mature lettuce by boring into mature heads, where they are difficult to find or control.

Females lay their eggs on leaves either singly or in small groups of less than five. The eggs are not protected. The generational time for this pest is similar to armyworms (monthly). Insecticide management is important, since the corn earworm has a history of developing resistance to various insecticides in several classes. The threshold for treatment is 1 larva per 2 plants from germination to heading, and 1 per 25 plants after head formation (9).

Cabbage Looper (Trichoplusia ni). Young cabbage looper larvae feed on the lower surface of outer leaves resulting in a windowpane appearance on the upper leaf surface. Older larvae feed through the leaves leaving large holes that frequently penetrate into the head. Most injury occurs after heading.

Eggs are deposited singly or in small groups of up to seven. Females can produce 300 to 600 eggs in their two-week life span. Larvae emerge from eggs in 3 to 4 days to feed on leaves. Larvae develop for 2 to 4 weeks, and then spin cocoons on the host plant for pupation. Adults emerge in five to ten days (9).

Aphids [green peach aphid (Myzus persicae), spirea aphid (Aphis spiraecola), potato aphid (Macrosiphum euphorbiae), and Uroleucon pseudambrosiae, among others]. Aphids are a primary pest for two reasons. First, the presence of aphids (live or dead) in the lettuce leaves puts the lettuce out of grade. In fact, many of the aphids are parasitized naturally, but the dead mummies do not rinse off of leaves. This is especially important for spring salad mix production, which must be free of these insects. Aphids are also important virus vectors (lettuce mosaic and bidens mottle mosaic). 
Aphids feed by piercing plant tissue with their needle-like mouthparts (stylets) and sucking out water and nutrients from the vascular system of the plant. Feeding damage and toxins in the saliva result in thickening, crumpling, and downward curling of leaves. Heavy aphid attack may kill very young plants. Aphids also deposit large amounts of honeydew on the plant surface, which encourages the growth of sooty mold. A short life cycle and asexual reproduction by live birth allows aphid populations to increase rapidly in Florida (9). Additionally, once the lettuce cups over the aphids late in the season, there are no systemic insecticides to control them (7).

Thrips (Frankliniella spp.). In agricultural areas, field disruptions (disking, mowing, chemical dessication) can drive thrips out of established areas and into less hardy vegetation (such as young lettuce plants). However, all stages of the plant are vulnerable to feeding damage. Large concentrations of thrips cause leaf damage (malformation) with their rasping mouthparts, and also can vector viruses such as tomato spotted wilt and tobacco streak virus. Thrips can complete a generation in lettuce in 14 to 20 days, but most of the development of the thrips that are feeding on vegetables occurs in adjacent weedy areas $(7,9)$.

Seedcorn Maggot (Delia platura). Seedcorn maggot reduces plant stand in lettuce by attacking young emerging seedlings. Adults of seedcorn maggot are small flies that become active early in the spring, laying their eggs where organic matter is high, such as in manure or where cover crops have been plowed under. Eggs are also laid at the base of transplants. Upon hatching, the maggots enter the seed or the stem of the developing seedling. Injury from seedcorn maggot feeding results in wilting and eventually death of the plant. Maggots feed on organic matter for two to three weeks, passing through three larval stages (instars) during that time. As the weather warms, the adult flies seek wooded areas, where the insect oversummers in the pupal stage. The flies are most active during cool, wet springs $(7,9)$.
Leafminers (Liriomyza sativae and Liriomyza trifolii). Leafminers were historically a major pest in lettuce production, but are now only occasionally a major pest of lettuce in Florida due to the use of spinosad. It is also believed that these flies are becoming resistant to spinosad (7).

The adult fly punctures the upper leaf surface while feeding, and the female inserts eggs into the puncture holes. When each larva (maggot) emerges, it feeds between the upper and lower leaf surfaces, creating a tunnel or mine that winds across the leaf and becomes larger as the maggot grows. When larval development is complete, the maggot cuts through the leaf surface and emerges from its mine, dropping to the soil to pupate. Where lettuce is grown on plastic mulched beds, leafminer pupae can be seen on the surface of the plastic. Leafminer populations can increase rapidly in Florida, where the life cycle can be as short as 14 to 21 days (9).

Cucumber Beetles [banded cucumber beetle (Diabrotica balteata) and spotted cucumber beetle (D. undecimpunctata howardi)]. Banded cucumber beetles are more common in southern Florida while spotted cucumber beetles are common in northern Florida (9).

Cucumber beetles prefer to feed on cucurbit plants like squash, cucumber, and cantaloupe, but can also feed on a wide range of crops, including corn, beet, pea, sweet potato, okra, lettuce, onion, cabbage, potato, and tomato. Spotted cucumber beetle, whose larvae are known as southern corn rootworm, is the more general feeder, having been recorded on more than 200 species of crops, grasses, and weeds. Feeding damage from adult cucumber beetles results in ragged holes in the leaves, and the beetles may also feed on stems. The larvae, which are found in the soil, may feed on the roots. The greatest effect on lettuce yield occurs when plants are attacked at the seedling stage. Older plants can withstand higher amounts of feeding damage $(12,13)$. 
Cucumber beetles have many generations each year. The life cycle of the banded cucumber beetle may be as short as 45 days under optimal conditions. Over a period of 2 to 8 weeks, each female banded cucumber beetle deposits between 2 and 15 clusters of up to 100 eggs each, in soil cracks, with up to 850 eggs being deposited by each female (12).

Seedcorn Beetles (Stenolophus spp.). These ground beetles deposit eggs in heavy, moist soils and are associated with emergence problems on uncleared or poorly fallowed land. Both larvae and adults are omnivorous, and will attack germinating seedlings (9).

Wireworms (Conoderus spp.). Wireworms, which are larvae of click beetles, are among the most destructive of soil insect pests. Soil treatment for these pest will be performed if the lettuce is being planted after sugarcane (which is a 3 to 5 year crop). If the lettuce follows sweet corn, no treatment is needed. Conoderus spp. wireworms, including C. rudis, C. amplicollis (Gulf wireworm), C. falli (southern potato wireworm), and $C$. verpertinus (tobacco wireworm), are the most common on vegetable crops in Florida. Wireworms cause the greatest damage to germinating seeds, and transplants are generally less susceptible. In addition to attacking seeds before or at germination, wireworms can bore into the tap root and tunnel up the stem or feed on smaller roots of seedlings. They can cause sudden stand reductions by quickly attacking young seedlings, causing wilting, stunting, and death. Click beetles lay their eggs in the soil near plant roots, and upon hatching, the wireworms feed on the nearby roots. Wireworms may spend up to several years in the soil in the larval stage and may be present at a soil depth of 1 to 5 feet $(7,11)$.

\section{Chemical Control}

In 2000 and based on a 2004 University of Florida (UF) survey, Florida growers applied insecticides on 98 to 100 percent of the state's lettuce acreage. During the years in which usage data have been collected, between 88 and 100 percent of lettuce acreage has been treated with insecticides each year, with total annual usage ranging from 1,900 to 4,900 pounds of active ingredient $(3,4,14-16)$. There was reported use in 2000 of abamectin, B.t. cyromazine, diazinon, imidacloprid, lambda-cyhalothrin, soaps, and spinosad and the UF survey results reveal use of azadirachtin, B.t., methoxyfenozide, pyrethrins, and spinosad (16). Other insecticides registered for lettuce in Florida in 2004 were acetamiprid, acephate, beet armyworm pheromone, bifenthrin (head lettuce only), buprofezin, carbaryl (bait and spray), cryolite, cypermethrin, dimethoate, disulfoton, emamectin (like abamectin head lettuce only), endosulfan, esfenvalerate, indoxacarb, malathion, methomyl, oils, oxydemeton (head lettuce only), permethrin, pymetrozine, tebufenozide, thiodicarb, and zetacypermethrin. Methoprene is available for fire ant control (9).

Azadirachtin (Neemix $\left.{ }^{\circledR}\right)$. Azadirachtin is a natural compound derived from the neem tree (Azadirachta indica) that has insect growth regulator activity. The compound is used to manage caterpillars and aphids. The post harvest interval (PHI) for azadirachtin is 1 day and the restricted entry interval (REI) is 4 hours. In 2004, lettuce growers in Florida applied azadirachtin three times per crop.

Bacillus thuringiensis. The biopesticide Bacillus thuringiensis (B.t.) is an important management tool for the Florida lettuce grower, who use it every year in the management of problematic caterpillars (armyworms, cabbage looper, cutworms, corn earworm). B.t. is a naturally occurring soil bacterium that produces spores and crystalline bodies that act as stomach poisons to the insects that consume it. The most common formulations are highly specific for caterpillars and therefore do not harm beneficial organisms. However, it is most effective against smaller larvae. The median price of B.t. is $\$ 10.00$ per pound (17). B.t. may be applied up to 
the day of harvest ( $\mathrm{PHI}=0$ days), and the REI under the Worker Protection Standard is 4 hours.

In 2004, Florida growers applied B.t. to 100 percent of their lettuce acreage, an average of 16 times. During the years in which usage data have been collected (1992-1998), lettuce growers in Florida have applied B.t. to between 2 and 58 percent of their lettuce acreage, making an average of 1.8 to 3.1 applications per crop $(3,4,14-16)$.

Spinosad (Spintor $\left.{ }^{\circledR}\right)$. Spinosad is a microbial fermentation product that is toxic to select insects, and as such, has negligible effects on populations of certain beneficial arthropods. Lettuce growers use it to manage mainly lepidopteran larvae and leafminers. The price of spinosad is $\$ 262.50$ per pound of active ingredient, and the approximate cost of a labeled application $(0.156 \mathrm{lb}$ ai/A) is $\$ 40.96(17,18)$. The REI is 4 hours and the PHI is one day. The label states that other chemistries should be used after three consecutive spinosad applications and there is a six application limit $(0.45 \mathrm{lb}$ ai/A) per crop. In 2004, lettuce growers in Florida applied spinosad (at $0.094 \mathrm{lb}$ ai/A) to their acreage 1.0 time $(17,18)$.

Methoxyfenozide (Intrepid $®)$. Methoxyfenozide, like tebufenozide, is an insect growth regulator that acts as a molt accelerator. These compounds only affect caterpillars, and lettuce growers use them to manage lepidopteran larvae. The price of methoxyfenozide is \$115.56 per pound of active ingredient, and the approximate cost of a labeled application ( $0.16 \mathrm{lb}$ ai/A) is $\$ 18.49(17,18)$. The REI is 4 hours and the $\mathrm{PHI}$ is one day. There is a $1.0 \mathrm{lb}$ ai/A per season application limit. In 2004, lettuce growers in Florida applied methoxyfenozide (at $0.12 \mathrm{lb}$ ai/A) to their acreage 5.0 times.

\section{Alternative Chemicals}

Over the past few years, there have been a number of new "reduced risk" materials registered for use on lettuce. Spinosad and methoxyfenozide are good examples of this trend. These materials are generally more selective than those of historic use. These materials are currently being assessed for fit into established IPM systems. Materials like beet armyworm pheromone are also being evaluated for attract and kill systems.

\section{Cultural Control}

Scouting is the number one cultural practice employed by lettuce growers, and all responded that production areas were scouted regularly. Growers also reported using mulches, removing field and perimeter vegetation, and plowing in residue as measures to clean up refugia and reduce local pest populations such as southern armyworm and thrips. They also reported altering planting date and rotating pesticides and crops. Though not reported in the survey, flooding is conducted on as many acres as possible during the summer, which alleviates some of the soil pests, such as cutworms, fire ant, and wireworms (7).

\section{Biological Control}

There is a measure of natural parasitism for most of the lettuce pests in Florida. However, most natural parasites don't control the pests at a rate that will preclude economic damage. Some growers are employing biological tools in their management programs. Lady bugs are released by these growers in an effort to manage aphids. Additionally, most growers go "soft" on early season insect management to encourage spider predation of aphids. Spod-X is an insecticidal virus for beet armyworm that is available for use in lettuce, although no growers reported its use. Researchers and extension personnel continue to examine biological management that looks promising (7). 


\section{Disease Management}

\section{Disease Pathogens}

In years of particularly wet weather, diseases constitute the most serious pest problem on lettuce in Florida. The state's warm, moist climate, as well as the overlapping progression of plantings during the season create conditions ideal for disease development. The most important diseases of lettuce are downy mildew (caused by Bremia lactucae), cercospora leafspot, and lettuce mosaic virus. Other minor diseases include bottom rot (caused by Rhizoctonia solani), drop (caused by Sclerotinia sclerotiorum) and the bacterial diseases corky root, soft rot, and leaf spot (5). Viruses such as tomato spotted wilt, bidens mottle mosaic, and tobacco streak are sporadic diseases which are viewed as emerging problems.

Downy Mildew (Bremia lactucae). For much of the 90's, downy mildew was not observed in the lettuce growing areas. However, there has lately been California lettuce transported into the growing area for salad mix preparation at the processing plant and outbreaks of this disease were found to correlate with this presence. Thankfully, the one company practicing this is now an exclusive sugarcane grower. When the disease does become established, it can easily affect 25 percent of the acreage if not 75 to 80 percent if an outbreak begins early. This fungus is resistant to mefenoxam. Although the EBDC fungicides are marginal on this fungus, the prophylactic program consists of maneb weekly or every 10 days (six times during the season), and all growers practice this program. If the disease is detected, more specific fungicides (azoxystrobin, fosetyl-Al, dimethomorph, cymoxanil+famoxadone) are used, with emphasis on rotation. Farmers generally disk in residue to destroy spores between crops (5).

Mature leaves are generally the main ones affected by downy mildew. It produces a yellow area on the upper surface of the leaves, and usually a white or grayish fluffy growth on the underside of the same leaf areas. The spots often merge to form large patches. It is capable of survival on a number of native weeds such as chicory, cudweed, sowthistle, and wild lettuce (19).

Leaf Spot (Cercospora longissima). Cercospora leaf spot is generally a fall disease due to the warm weather. It generally affects less than 5 percent of the acreage with similar loss values (i.e., $<5$ percent). The disease is generally controlled incidentally with the same prophylactic program of maneb. However, inoculum comes in from weeds, so keeping clean ditch banks and disking down harvested fields are the cultural practices used to reduce this disease (5).

Lettuce Mosaic Virus (LMV). Seed testing for this disease began in the early 80s and all seed planted must be certified as containing less than 1 virus-infected seed in 30,000 seeds. It has been an effective program, but even with it an outbreak occurred in 1997. Symptoms of LMV include vein clearing, mosaic, and stunting. Wrapper leaves are duller in appearance, typically folded backward, and exhibit more marginal serration. Romaine lettuce types exhibit similar signs plus a leaf blistering. Butterhead lettuce exhibits stunting and severe chlorosis $(5,19)$.

Tomato Spotted Wilt Virus (TSWV). This virus was first seen in 2004 in the Okeechobee area, which is separate from the main growing area near South Bay. This virus is vectored by thrips which have become increasing pests. Consequently, the incidence of this virus will probably increase in future years (5).

Bottom Rot (caused by Rhizoctonia solani). Bottom rot is observed every year during warm wet weather periods. Less than five percent of acreage is affected by this, but it can approach 100 percent in some rare cases. It generally affects iceberg, Boston, and bibb varieties more 
than romaine, and the usual outcome is loss of just a few wrapper leaves. No variety claims resistance, and there is no economical pesticide used for the management of this disease. Since much of the irrigation (when needed) is provided through seepage, growers keep this level as low as possible without causing water stress to the crop (5).

Leaf petioles that touch the soil surface become rust colored and slightly sunken prior to leaf decay. Infection may spread upward through the head or leaf canopy, destroying the entire plant. Brown strands of the fungus may be observed on severely affected plants, and black sclerotia may form near the soil level (19).

Drop (caused by Sclerotinia sclerotiorum). Lettuce drop generally becomes a problem only when the land is unable to be flooded during the summer. Flooding usually provides complete control, but the fungus may be a problem once every 10 or 20 years. Yearly losses range between one and two percent. As with bottom rot, chemical control is too expensive for management (5).

The first sign of the disease is a progressive wilt of older and then younger leaves, and outer leaves collapse around plants in a fan pattern. The inner leaves become soft, dry rapidly, and turn dark in color. There is usually a heavy mycelial growth around the main stem. As the plant dies, numerous black irregular bodies (sclerotia) develop on and in the diseased tissue. These will persist for many years in the soil if not inactivated by flooding (19).

Bacterial Diseases (caused by Rhizomonas suberfaciens, Erwinia carotovora pv. carotovora, Xanthomonas campestris pv. vitians, Pseudomonas secorii, and Pseudomonas marginalis pv. marginalis). Based on variety, seeding rate, and weather conditions, bacteria may affect root, leaves, or the entire plant $(5,19)$.

Bacterial corky root rot (caused by Rhizomonas suberfaciens) is widespread throughout the growing area. Certain varieties of lettuce claim resistance to this disease and rotation is used as well, but the bacterium still survives in the soil. The disease is characterized by corkiness of the outer portions of the taproot, necrosis of the tip of the taproot, and reduced fibrous root mass. The tissue of the taproot may be discolored and in advanced cases, may disintegrate or become hollow $(5,19)$.

When weather is especially wet, bacterial soft rot (caused by Erwinia carotovora pv. carotovora) can decimate the entire crop, but usually causes less than five percent damage in any given year. Growers keep the water level as low as possible during these times of inundation. Affected plants decompose rapidly in a loose, wet mass in the field. Although this soft rot is correlated with mechanical injury, it can affect internal leaves within a head of lettuce and not be apparent from the external surface $(5,19)$.

A number of bacteria (Xanthomonas campestris pv. vitians, Pseudomonas secorii, and Pseudomonas marginalis pv. marginalis) can affect the leaves of lettuce, either in the field or after the plant has been shipped. Seed is certified, but seeding rate of the spring salad mix can result in a virtual canopy over the entire field. Copper is often sprayed if there is wind or rain, since most recovered strains are sensitive to this metal. Some growers are using phage as a way to manage bacteria. Lettuce varieties are differentially sensitive to certain bacteria. For $X$. campestris pv. vitians, which causes a "peppery" appearance of black lesions, romaine-type lettuces are generally more susceptible, while butterheads are less susceptible $(5,19)$.

\section{Chemical Control}

In 2000, Florida growers applied fungicides on 86 percent of the state's lettuce acreage. During the years in which usage data have been collected, between 65 and 98 percent of lettuce acreage has been treated with fungicides each year, with total annual usage ranging from 4,400 
to 6,900 pounds of active ingredient $(3,4,14-16)$.

There was reported use in 2000 of copper (sulfate or hydroxide), maneb and sulfur (16). Other fungicides or disease-preventing products registered for use in lettuce in Florida in 2004 were acibenzolar, azoxystrobin, Bacillus subtilis, copper octanoate, cymoxanil/famoxadone, dicloran, dimethomorph, fludioxonil (seed treatment only), fosetyl-Al, iprodione, mefenoxam, potassium bicarbonate, and phosphoric acid solutions.

Maneb. Maneb is an ethylene(bis) dithiocarbamate (EBDC) fungicide which is used prophylactically, primarily for the management of downy mildew (20). It is applied every 7 to 10 days (6 times during the crop) at an average rate of $1.6 \mathrm{lb}$ ai/A. The median price of maneb is $\$ 4.00$ per pound of active ingredient, and the approximate cost per labeled application (1.6 lb ai/A) was $\$ 6.40$ per acre $(17,21)$. Maneb may be applied up to ten days before harvest (PHI=10 days), and the REI under the Worker Protection Standard is 24 hours. No more than 9.6 pounds of active ingredient per acre may be applied during a season (21).

Coppers. Lettuce growers in Florida use copper (hydroxide or sulfate) for the management of downy mildew and bacterial diseases (20). The median price of copper hydroxide is \$2.11 per pound of active ingredient, and the approximate cost per labeled application (1.54 lb ai/A) was $\$ 3.25$ per acre $(17,21)$. Copper hydroxide may be applied up to the day of harvest, but the REI under the Worker Protection Standard is 24 hours.

Sulfur. Sulfur is used as a prophylactic control agent for a number of disease pathogens. The median price of sulfur is $\$ 0.88$ per pound and the approximate cost per labeled application (10 lb/A) is $\$ 8.80$ per acre $(17,22)$. The REI for sulfur is 24 hours and there is no PHI.

\section{Alternative Chemicals}

In addition to strobilurin fungicides such as azoxystrobin, several other new fungicides have been registered for use in lettuce. Acibenzolar (for viral and bacterial pathogens), dimethomorph, cymoxanil/famoxadone, phosphites (for downy mildew), and fludioxonil (for soil-borne pathogens) are materials that are just now being examined for overall utility in Florida lettuce production.

\section{Cultural Control}

Scouting is the number one cultural practice employed by lettuce growers, and all responded that production areas were scouted regularly. Growers also reported using mulches, removing field and perimeter vegetation, and plowing in residue as measures to reduce inoculum reservoirs in the immediate vicinity. They also reported altering planting date and rotating pesticides and crops. Although not reported by survey, it is known that flooding is one of the cultural controls employed by everyone who is capable; but sometimes the water management district does not allow this practice (5).

\section{Biological Control}

The one area of active biological pest management is phage use. These bacterial viruses have been increasingly more successful at reducing bacterial diseases. Continuing research helps to determine the best time in the disease cycle to apply phage, as well as the best environmental conditions for phage infection. 


\section{Nematode Management}

\section{Nematode Pests}

Nematodes are microscopic roundworms living in the soil which feed on plant roots and damage the tissue. Since most of the commercial lettuce production is associated with muck soils, which have historically few nematode problems due to flooding, little management is practiced. There was some reported use of methyl bromide in 2000, but since this crop did not receive a critical use exemption, the use of this gas will have ceased by the end of 2004 (16). In fact, most soil sterilants are too expensive for lettuce growers to use. For those growers attempting to grow lettuce on sandy soils, or soils more conducive to nematode damage, dichloropropene and metam sodium are labeled for this use.

\section{Weed Management}

\section{Weed Pests}

Since lettuce is a quick-growing, short season crop, weed competition in the early emergence period is a critical consideration. For example, one pigweed will reduce the quality of the four lettuce plants around it, and competition within the first five weeks can easily cut the yield in half (23). As stated earlier, thinning and weeding is done from three to four weeks after seeding. Ten percent of the growers (those that use no herbicide) will hand cultivate once again before harvest (at a cost of approximately \$800/acre). The remaining lettuce is grown with some type of herbicide.

A variety of weeds are problematic for Florida lettuce producers, including nutsedges (yellow and purple), grasses such as goosegrass, and broadleaf weeds, such as pusley and purslane. Amaranths (livid, spiney, or common) are particularly troublesome (23).
Amaranth (Amaranthus spp.). Amaranths (pigweeds) are annual broadleaf herbs with erect stems that can grow to six feet tall. Several species of amaranth are present in lettuce growing areas, including livid amaranth (Amaranthus lividus), smooth pigweed (Amaranthus hybridus), and spiny amaranth (Amaranthus spinosus). Amaranths reproduce solely by seed, producing very small, dark seeds. They prefer open areas with bright sunlight $(24,25)$.

Nutsedge (Cyperus spp.). Yellow nutsedge (C. esculentus) and purple nutsedge (C. rotundus) are problems in Florida lettuce production. Both of these perennial sedges are found in disturbed habitats throughout Florida and the southeastern U.S. Yellow nutsedge may produce some seeds, but reproduces primarily by rhizomes and tubers. The parental plant develops rhizomes, which end in bulbs or tubers that produce new plants. Tuber production is favored by low nitrogen levels and high temperatures (80 to $91^{\circ} \mathrm{F}$, or 27 to $33^{\circ} \mathrm{C}$ ). The plant is tolerant of high soil moisture but is intolerant of shade. Purple nutsedge is also able to reproduce from tubers when conditions are harsh, making it difficult to control. Unlike the rhizomes of yellow nutsedge, purple nutsedge rhizomes growing off the parent plant produce new plants in a series ("tuber-chains"). The plant also reproduces by seed to a limited degree. Although purple nutsedge is also intolerant of shade, it is able to survive a wide range of environmental conditions, growing well in nearly all soil types and over a range of soil moisture, soil $\mathrm{pH}$, and elevation. Purple nutsedge is also able to survive extremely high temperatures (24).

Goosegrass (Eleusine indica). Goosegrass is similar in appearance to crabgrass, but grows more densely. It is also a summer annual, and it prefers sunny, moist conditions. Reproducing by seed, it flowers from July to October $(24,25)$.

Florida Pusley (Richardia scabra). Florida pusley is a loosely branched annual that stands erect or lies flat on the ground. Its hairy stems and oppositely arranged leaves are often rough in 
texture, particularly along the main veins. The plant is often mixed with Brazilian pusley $(R$. brasiliensis). Florida pusley reproduces by seed and blooms in any month in the absence of frost (26).

Purslane (Portulaca oleracea). Purslane is a broadleaf summer annual with a single taproot from which multiple branched, purplish-red stems often form large mats. Clusters of small leaves are found at the end of its branches. The plant reproduces by seed, flowering from August to October. Being resistant to drought, it is difficult to kill. However, it is susceptible to frost injury $(24,25,27)$.

\section{Chemical Control}

In 2000, Florida growers applied herbicides on 88 percent of the state's lettuce acreage. During the years in which usage data have been collected, between 56 and 98 percent of lettuce acreage has been treated with herbicides each year, with total annual usage ranging from 500 to 4,100 pounds of active ingredient $(3,4,14-16)$. There was reported use in 2000 of imazethapyr, paraquat, pronamide, and sethoxydim (16). Other herbicides registered for use in lettuce in Florida in 2004 were benefin, bensulide, clethodim (leaf lettuce only), fluazifop, glyphosate, pelargonic acid, and trifluralin. Following label directions when applying herbicides is essential. Some of the preemergence herbicides are specific for mineral sands (benefin, trifluralin, and pronamide), while others will work in muck soils (bensulide and imazethapyr).

Imazethapyr (Pursuit ${ }^{\circledR}$ ). Imazethapyr is an imazolidinone herbicide which can be used either preemergence or postemergence. It is used to manage many annual weeds. Its use is under special local needs (SLN) registration FL-960005 and a signed authorization and limit of warranty and liability waiver must be on file with Third Party Registrations Inc. to use the herbicide. The median price of imazethapyr is $\$ 343$ per pound of active ingredient, and the approximate cost per labeled application (0.03 lb ai/A) was \$10.29 per acre $(17,23)$. Imazethapyr may be applied up to 30 days before harvest ( $\mathrm{PHI}=30$ days), and the restricted entry interval (REI) under the Worker Protection Standard is 12 hours.

Paraquat (Gramoxone ${ }^{\circledR)}$ ). Paraquat is a nonselective bipyridilium herbicide used to manage many annual and perennial weeds. The median price of paraquat is $\$ 19.97$ per pound of active ingredient, and the approximate cost per labeled application (0.94 lb ai/A) was \$18.77 per acre $(17,23)$ when used prior to lettuce emergence, but only $\$ 9.39$ when used for row middle control with a shielded sprayer. Its use is under special local needs (SLN) registration FL-010004. Paraquat may be applied up to harvest and the REI is 24 hours.

Pronamide $(\operatorname{Kerb} \AA)$. Pronamide is a preemergence amide herbicide used to manage germinating annuals. The median price of pronamide is $\$ 49.58$ per pound of active ingredient, and the approximate cost per labeled application (1.5 lb ai/A) was \$74.37 per acre $(17,23)$. The PHI for pronamide is 55 days and the REI is 24 hours.

Sethoxydim (Poast $\left.{ }^{\circledR}\right)$. Sethoxydim is a cyclohexene, postemergence herbicide used to manage many annual and perennial grass weeds. It does not control sedges or broadleaf weeds. The median price of sethoxydim is $\$ 47.45$ per pound of active ingredient, and the approximate cost per labeled application (0.28 lb ai/A) was $\$ 13.35$ per acre $(17,23)$. Sethoxydim may be applied up to 15 days before harvest for leaf lettuce, but the PHI is 30 days for head lettuce, and the REI is 12 hours. A maximum of 0.56 pounds of active ingredient over the season may be applied per acre.

\section{Chemical Alternatives}

One of the few new herbicides on the horizon for lettuce is carfentrazone, which received a tolerance for lettuce at the end of September, 
2004. Since lettuce production has decreased rapidly in Florida, there are concomitantly less requests for IR-4 assistance.

\section{Cultural Control}

Although flooding is done for disease management reasons, this practice also aids in weed control to some extent. A certain portion of weed seed is inactivated by prolonged flooding. Even though lettuce is a short season crop, there is probably more hand weeding than most other Florida crops. There is manual removal at thinning and blocking, and again a few weeks later if the herbicide performs poorly or one is not used. Growers also reported using mulches as another way to reduce weed growth.

\section{Key Contacts}

- Michael Aerts is the assistant director of the Environmental and Pest Management Division of the Florida Fruit and Vegetable Association. He facilitates communication between commodity groups and regulatory agencies. Mr. Aerts can be reached at: 800 Trafalgar Ct. Suite 200 Maitland, FL 32794 (321) 2145200, mike.aerts@ffva.com.

- Mark Mossler is a pesticide information specialist for the Food Science and Human Nutrition Department's Pesticide Information Office at the University of Florida's Institute of Food and Agricultural Sciences. He is responsible for providing pesticide information to the public and governmental agencies. Mr. Mossler can be reached at UF/IFAS PIO, Box 110710, Gainesville, FL 32611, (352) 392-4721, mamossler@ifas.ufl.edu.

\section{References}

1. U.S. Dept. of Agriculture/National Agricultural Statistics Service. (2004). 2002 Census of Agriculture. National Agricultural Statistics Service. Available: http://www.nass.usda.gov/

2. Hochmuth, G.J., Hanlon, E., Nagata, R., Snyder, G. and Schueneman, T. (1994). Fertilization Recommendations for Crisphead Lettuce Grown on Organic Soils in Florida. Horticultural Sciences Department document SP153. Florida Cooperative Extension Service, Institute of Food and Agricultural Sciences, University of Florida.

3. U.S. Dept. of Agriculture/National Agricultural Statistics Service. (1999). Agricultural Chemical Usage, Vegetables, 1998 Summary. Agricultural Statistics Board, National Agricultural Statistics Service, U.S. Department of Agriculture. Available:

http://usda.mannlib.cornell.edu/reports/na ssr/other/pcu-bb/

4. U.S. Dept. of Agriculture/National Agricultural Statistics Service. (1993). Agricultural Chemical Usage, Vegetable Crop Summary 1992. Agricultural Statistics Board, National Agricultural Statistics Service, U.S. Department of Agriculture. Available: http://usda.mannlib.cornell.edu/reports/na ssr/other/pcu-bb/

5. Raid, Richard, Plant Pathologist. Personal communication, University of Florida, Everglades Research and Education Center, Belle Glade. 2004.

6. Maynard, D.N., Hochmuth, G.J., Vavrina, C.S., Stall, W.M., Kucharek, T.A., Webb, S.E. (2003). Lettuce, Endive, and Escarole Production in Florida. Horticultural Sciences Department 
HS728. Florida Cooperative Extension

Service, Institute of Food and

Agricultural Sciences, University of

Florida.

7. Nuessly, Gregg, Crop Protection Specialist. Personal communication. University of Florida, Everglades Research and Education Center, Belle Glade. 2004.

8. Stall, Bill Weed Scientist. Personal communication with University of Florida, Gainesville. 2004.

9. Nuessly, G.N. and Webb, S.E. (2003). Insect Management for Leafy Vegetables (Lettuce, Endive, and Escarole).

Entomology \& Nematology Department document ENY-475. Florida Cooperative Extension Service, Institute of Food and Agricultural Sciences, University of Florida.

10. Capinera, J.L. (1999). "Fall armyworm.” UF/IFAS Features Creatures. EENY-98. Available: http://www.ifas.ufl.edu/ insect/field/fall armyworm.htm

11. Johnson, F.A. and Stansly, P.A. (1999). Insects That Affect Vegetable Crops. Entomology and Nematology Department ENY 450. Florida Cooperative Extension Service, Institute of Food and Agricultural Sciences, University of Florida.

12. Capinera, J.L. (1999). "Banded cucumber beetle”. UF/IFAS Featured Creatures EENY-93. Available: http://www.ifas.ufl.edu/veg/bean/banded cucumber beetle.htm

13. White, R.E. (1964). Injurious beetles of the genus Diabrotica (Coleoptera: Chrysomelidae). Entomology Circular No. 21. Florida Department of
Agriculture and Consumer Services, Division of Plant Industry, Gainesville, Florida.

14. U.S. Dept. of Agriculture/National Agricultural Statistics Service. (2001). Agricultural Chemical Usage, Vegetables, 2000 Summary. Agricultural Statistics Board, National Agricultural Statistics Service, U.S. Department of Agriculture. Available: http://usda.mannlib.cornell.edu/reports/na ssr/other/pcu-bb/

15. U.S. Dept. of Agriculture/National Agricultural Statistics Service. (1997). Agricultural Chemical Usage, Vegetables, 1996 Summary. Agricultural Statistics Board, National Agricultural Statistics Service, U.S. Department of Agriculture. Available: http://usda.mannlib.cornell.edu/reports/na ssr/other/pcu-bb/

16. U.S. Dept. of Agriculture/National Agricultural Statistics Service. (1995). Agricultural Chemical Usage, Vegetable Crop Summary 1994. Agricultural Statistics Board, National Agricultural Statistics Service, U.S. Department of Agriculture. Available:

http://usda.mannlib.cornell.edu/reports/na ssr/other/pcu-bb/

17. Helena Chemicals. Personal communication. Alachua, FL, 2004.

18. Dow labels, Midland, MI.

19. Pernezny, K. and Raid. R. (2004). 2004 Florida Plant Disease Management Guide: Lettuce and Endive. Department of Plant Pathology document PDMG-V340. Florida Cooperative Extension Service, Institute of Food and Agricultural Sciences, University of Florida. 
20. Kucharek, T. (2004). Chemical Control Guide for Diseases of Vegetables.

Available: http://edis.ifas.ufl.edu/PG100

21. Griffin labels, Valdosta, GA.

22. Cerexagri labels, Philadelphia, PA.

23. Stall, W.S. and Dusky, J.A. (2003). Weed Control in Leafy Vegetables (Lettuce, Endive, Escarole, and Spinach). Horticultural Sciences Department document HS203. Florida Cooperative Extension Service, University of Florida, Institute of Food and Agricultural Sciences.

24. Miller, J.F., Worsham, A.D., McCormick, L.L., Davis, D.E., Cofer, R. and Smith, J.A. (1975). Weeds of the Southern United States. Florida Cooperative Extension Service, Institute of Food and Agricultural Sciences, University of Florida. Gainesville, Florida.

25. Lorenzi, H.J. and Jeffery, L.S. (1987). Weeds of the United States and Their Control. Van Nostrand Reinhold Company, New York.

26. Stall, W.M. (2003). Weed Control in Cucurbit Crops (Muskmelon, Cucumber, Squash, and Watermelon). Horticultural Sciences Department document HS190. Florida Cooperative Extension Service, University of Florida, Institute of Food and Agricultural Sciences.

27. Stephens, J.M. (1994). Purslane Portulaca oleracea L. Horticultural Sciences Department Fact Sheet HS-651, Florida Cooperative Extension Service, Institute of Food and Agricultural Sciences, University of Florida. 